\title{
Pragmatic Arguments in the Qur'ān for Belief
}

\author{
M. Shabid Alam
}

July 27, 2011

Professor of Economics

Northeastern University

Boston, MA 02115

m.alam@neu.edu

\begin{abstract}
Unlike other scriptures, the Qur'an engages man as he is, that is, man as a composite of opposing tendencies. It guides the believer as much as it strives to save the disbelieving skeptic. In speaking to the skeptic, the Qur'an uses all the resources of rhetoric that have a chance of softening his disbelief and bring him back to his spiritual home. This essay examines two sets of pragmatic arguments in the Qur'an for belief, both based on a system of divine accountability: in one the accounting occurs in afterlife, in the other it occurs in this life. In presenting the first argument, the Qur'an anticipates Pascal's wager. This argument is later taken up by 'Ali, Islam's fourth orthodox caliph, and Al-Ghazzali. Further, it is shown that religions generally, and Islam in particular, establish the contain the premises for enunciating Pascal's wager.
\end{abstract}




\section{Other Qur'anic Essays:}

1. Alam, M. Shahid, The Qur'anic Paradigm: A Contest Over Man (November 9, 2010). Available at SSRN: http://ssrn.com/abstract=1706449

2. Alam, M. Shahid, Ishmael and Isaac: An Essay on the Divergent Moral Economies of the Qur'an and the Torah (July 1, 2010). Available at SSRN:

http://ssrn.com/abstract $=1715104$ 
Say: 'Have you ever thought: what if this revelation

really is from God and you still reject it?

Qur'an (Fussilat/41, 52) ${ }^{1}$

More than any other scripture, the Qur'an engages the skeptic who mocks and challenges its metaphysical claims. Unafraid, the Islamic scripture admits this disbeliever into its discourse, allowing him to argue against the prophets, accuse them of sorcery, and dare them to do their best to dislodge him from his disbelief. Occasionally, the Qur'an even allows the prophets to voice their discomfort with metaphysical claims, for they too are human and seek confirmation of these claims in sensory experience.

The Qur'an speaks to man in a variety of rhetorical modes, seeking to bring him back to the straight path, to raise him from the lowest of the low to the finest state in which he was originally created. ${ }^{2}$ It draws man to God by pointing to His myriad creations, from something as small as a gnat to the heavens raised without any visible support. It asks man to look around, he will not see any flaw in God's creation; to observe how the Lord holds up the birds spreading and closing their wings; to see the ships, sailing like floating mountains; to ponder on how livestock produces pure milk, sweet to the drinker from ; etc. Thus, by reflecting upon the order and beauty of the heavens and earth, the Qur'an expects that men and women will begin to discern in them the signs of their Creator.

In order to awaken man to a recognition of his higher calling, God uses a variety of logical and rhetorical devices. It appeals to his powers of observation, reasoning, imagination, moral sense and aesthetic faculties, as well as his anxieties, fears and hopes. God gave leave to some of his prophets to dazzle their audience with miracles: to Muhammad he gave the miracle of the Qur'an which unremitting- 
ly engages in reasoned discourse with men and women of diverse capacities and tendencies. The Qur'an appeals to man's intellect.

If the Qur'an engages endlessly in reasoned discourse, it also knows that this epistemic approach to belief will not work for everyone. ${ }^{3}$ Indeed, most people will not believe, however eagerly you may want them to. For men and women whose intellect cannot be awakened to an awareness of metaphysical realities, the Qur'an employs pragmatic arguments that appeal to their regard for their own happiness. It will be the task of this essay to examine these arguments. In particular, we will show that the pragmatic argument(s) associated with Blaise Pascal - the brilliant French mathematician, mystic and theologian of the $17^{\text {th }}$ century - were anticipated by the Qur'an in the seventh century, and then taken up by Ali, Muhammad's first cousin and the fourth of the orthodox caliphs, and Al-Ghazzali, the great Islamic theologian of the $11-12^{\text {th }}$ centuries.

Pragmatic arguments for belief may appeal to individual prudence based on the chance of an afterlife; or they may invoke real or imagined benefits that belief may confer on individuals or societies in this life. Both arguments are found in the Qur'an, but this essay will focus on arguments of the first type. In particular, we examine the wager that the Qur'an implicitly proposes to the skeptics, one that is similar in its essentials to a common version of Pascal's wager. Implicitly, the Qur'anic wager satisfies all the conditions set out by William James for such a wager to have force.

The most common version of Pascal's wager is quickly summarized. "Either God is or he is not." Since reason is of no help in choosing between the two - and you must choose - reason itself 
demands that you consult your "happiness" and choose the option that holds the prospect of bringing greater happiness. You compare the gains and losses that will flow from the two choices either God is or he is not - and choose the belief from which you expect to receive the greater gain. Let us suppose that you have placed a wager on God. In this case, "if you win you win everything, if you lose you lose nothing." "Do not hesitate then," Pascal concludes, and "wager that he does exist."4 Wager on God because the outcomes for believing are either superior to or no worse than those for disbelief. ${ }^{5}$ This argument is pragmatic because it makes utility - in the absence of evidence - the criterion for forming beliefs.

The Qur'an makes a similar argument in the epigraph to this essay as well as in other ayaat (plural of ayat, verse or sign) that we shall examine in the next section. ${ }^{6}$ First, consider the context of the what if argument in this ayat. It appears nearly at the end of surah Fussilat, a chapter that deeply engages those who doubt that they will meet their lord. (54) The chapter begins with a dare to the blessed Prophet from the pagans of Mecca. They say, 'Our hearts are encased against what you call us to; our ears are heary; there is a barrier between us and you. So you do whatever you want, and so shall we.' This surah and indeed the entire Qur'an may be read as offering answers to this challenge using a variety of arguments. Surah Fussilat draws attention to the origins of the cosmos: how God created the heavens and earth from smoke. It reminds the pagans of the blast that destroyed 'Ad and Thamud - two ancient peoples of Arabia warns them of the Day, when God's enemies are gathered up for the Fire and driven forward, a Day on which they will not be allowed to make amends; it draws attention to His signs, and tells the pagans that if 
God can revive the dead earth, he can certainly give life to the dead. It is at this point - that is, after sustained attempts to weaken the pagan's rejection of the Qur'an - that God asks Muhammad (s) to make the pragmatic argument.

It is clear from Fussilat - as it is from other suwar (plural of surah) in the Qur'an - that the pagans directed their skepticism most frequently against the notion of an afterlife. 'There is only the life of this world:' the pagans declare categorically in surah al-Mu'minun, 'we die, we live, but we will never be resurrected. ${ }^{8}$ It would appear that the pagans have made their choice: they have chosen this life over the one beyond the grave. In particular, they find it implausible that the dead will be resurrected on the Day of Judgment.

The Qur'an meets the pagans' skepticism on their own ground, with a rational appeal to their self-interest. It begins by asking, Have you ever thought: what if this Qur'an really is from God and you still reject it? ${ }^{9}$ Implicit in this question is the same wager that is set up by Pascal. 'Either the Qur'an is from God, or it is not. If the Qur'an is from God, there is afterlife, there is an eternity in Hell for disbelievers, etc. The converse holds if the Qur'an is not from God. These are your only options: and you have to choose one or the other. You have chosen to reject the Qur'an, together with its belief in an afterlife. You are cocky about your choice: you think that afterlife is a lie and, therefore, you have nothing to fear from death. ${ }^{10}$ Your smugness is insupportable: can you be sure that you have not erred in rejecting the Qur'an? What if you are wrong, what if this Qur'an really is from God? If it is from God and you still reject it, you will suffer eternally in the fires of Hell. Rationally considered, then, you would want to avoid this risk at all costs. Avoidance is simple: believe in the Qur'an. Believe in this revelation - 
God is saying - because this guarantees avoidance of eternal punishment. $^{11}$

Without any reference to Pascal's wager, the influential Pakistani scholar, Sayyid Abul A'ala Maududi, offers a similar tafseer (interpretation) of the what-if ayat from Fussilat. ${ }^{12}$ It is not the course of wisdom - Maududi points out - to reject the Qur'an. This rejection is not based on certain knowledge, but is a matter of speculation; hence, those who reject the Qur'an could be wrong. If the disbeliever's position is the correct one, death will usher him and the believer into the same oblivion. One will not be better off than the other. On the other hand, if the Qur'an is from God and all that the Qur'an promises comes true, the disbeliever's plight will be a very sorry one. Now, therefore, the self-interest of the disbeliever indicates that he should give up his opposition to the Qur'an. Nevertheless, Maududi shrinks from regarding this as an argument for embracing belief. Instead, he maintains that the Qur'an urges the pagans not to use a merely speculative position to oppose others from turning to the Qur'an.

The Qur'an's what-if question would carry no force if the pagan's rejection of its divine origin was categorical; but that is not always the case. ${ }^{13}$ In Fussilat, God speaks thus of the arrogance of disbelieving man: Whenever We let him taste some of Our mercy after be has been afflicted, he is sure to say, 'This is all my doing: I do not think the Hour will ever come, but even if I were to be taken back to my Lord, the best reward would await me with Him. ${ }^{14}$ Similarly, in surah Ibrabim, the disbelievers among the people of Noah, 'Ad and Thamud tell the prophets who were sent to them, ' $W$ e do not believe the message you were sent with. We have disturbing doubts about what you are asking us to 
do.' For pagans who reject afterlife categorically, the Qur'anic wager would fall on deaf ears.

Often the Qur'an will return again and again to a subject it considers important. So it is with the pragmatic arguments for belief that appeal to our prudence. ${ }^{15}$ Two variants of these arguments occur in the Qur'an: they take the form of wagers that depend on accountability in afterlife and here on earth.

The Qur'an presents the pragmatic arguments in several voices. In a few cases, God makes the pragmatic argument, speaking in his own voice. More frequently, Muhammad is asked to use these arguments in his exchanges with the Arab pagans; on other occasions, Noah, Abraham, Shu'ayb and Hud employ these argument in debates with their own people. In surah Ghafir, a secret believer from the Pharaoh's family uses the pragmatic argument when pleading for the life of Moses. ${ }^{16}$

If the Qur'an repeatedly uses pragmatic arguments to make the case for belief, that is not only because the Prophet (s) was sent to mostly unbelieving Arabs, among the last people in the Middle East who had not been converted to a revealed religion. Nearly all the prophets mentioned in the Qur'an encounter disbelievers who use reasoning and ordinary experience to reject divine revelation, afterlife and bodily resurrection. "A reasoning mind," writes Bahauddin - father of Jelaluddin Rumi - "cannot approach revelation."," Skepticism raises its head whenever excessive use of the rational faculty atrophies other modes of knowing. The Qur'an speaks to the skeptic because he is present in all ages and societies.

The Afterlife, the Day of Judgment, Heaven and Hell are 
overwhelming facts in the Qur'anic discourse about God's relationship to man. In consequence, the Qur'an frames one variant of the pragmatic argument - in which man must choose between belief and unbelief - in terms of this eschatology. ${ }^{18}$ Once we examine the context of the what-if question in the epigraph to this essay, it becomes clear that it draws attention to the consequences of rejecting faith that will unfold in the life beyond the grave.

As if to emphasize the importance of the what-if question in the epigraph, the Qur'an repeats it with a minor change in surah Al-Ahqaf. ${ }^{19}$ Replacing this Qur'an with this [revelation], here God asks the same question, 'Have you thought, what if this Qur'an really is from God and you reject it? In surah Luqman, the Qur'an presents a more transparent formulation of this argument. When they are told, Follow what God has sent down,' they say: 'We shall follow what we saw our forefathers following. What! Even if Satan is calling them to the suffering of the Blazing Flame? Here, the Qur'an spells out the consequence of rejecting faith; the rejecters will burn in Hell.

In two other formulations of the what-if argument, the Qur'an backs up the what-if argument by drawing attention to its authority, the source upon which it flows. ${ }^{20}$ In surah $\mathrm{Hud}$, when the Midianties call into question Shu'ayb's invitation to belief and charity, he answers 'My people, can you not see? What if I am acting on clear evidence from my Lord? This may be expanded as follows: 'My people, you have chosen to reject my call to believe in God. What if I am acting on clear evidence from my Lord? That is to say, what if I am right and you are wrong? In that event, your error will be very costly.' Earlier, in the same surah, Noah confronts his people with a similar question, 'My people, think: if I did have a clear sign from my Lord, and He had given me grace of His own, though it was hidden from you...' In 
these ayaat, both prophets are invoking the higher experiential basis of their invitation to belief. Hud is acting on clear evidence from God; likewise Noah has solid proof from God even though the unbelievers cannot see it. The prophets speak from a position of knowledge; they know for a certainty that there is an afterlife. Their task - in the Qur'an - is to convince their interlocutors to make the correct wager.

In one formulation of the pragmatic argument, The Qur'an pointedly invites the disbeliever to compare the gains and losses from belief. ${ }^{21}$ After speaking of the bumiliating punishment that awaits people who are arrogant, boastful, miserly, and do not believe in Him and the Last Day, the Qur'an directly asks them to ponder over the consequences of believing: What harm would it do them to believe in God and the Last Day, and give charitably from the sustenance God has given them? This is an invitation to the disbeliever not only to weigh the gains and losses from belief but to compare them against the gains and losses that might flow from unbelief. The Qur'an expects that this weighing of belief and unbelief will show that the balance of advantages favor the believer. If the unbeliever switched from unbelief to belief this change could not harm him: on the contrary it would bring clear and inestimable gains.

In the Qur'an, God also renders judgment on the living: he rewards some believers and punishes some unbelievers on earth. ${ }^{22}$ Divine retribution for disbelieving nations is a recurring theme in the Qur'an. Nearly always, when the Qur'an speaks of previous prophets, it recalls how their people disobeyed their warnings and were destroyed for their disbelief. It speaks repeatedly of the punishments the Jews invited upon themselves for disobeying their prophets. The people of Noah disbelieved long before these [Meccan] disbe- 
lievers, as did the people of Rass, Thamud,/'Ad, Pharaoh, Lot, / the ForestDwellers, Tubba': all of these people disbelieved their messengers, and so My warning was realized. Although they are not as frequent as warnings of punishments in afterlife, the Qur'an makes it clear that God intervenes in history not only to give guidance, he also rewards and punishes individuals and nations in historical time.

Compared to the pragmatic arguments framed in terms of afterlife, many more invoke punishment in this life. Since the Qur'an was seeking to persuade a disbelieving people, skeptical of belief in afterlife, warnings of imminent and sudden losses were likely to produce a stronger effect than distant and uncertain punishments in an afterlife. In several passages, the Qur'an seeks to overthrow the disbeliever's hubris, their boasting that they are masters of their fate. Here are a few examples of the wager framed in terms of consequences of unbelief in this life.

Do the people of these towns feel secure that Our punishment will not come upon them by night, while they are asleep? / Do the people of these towns feel secure that Our punishment will not come upon them by day, while they are at play? / Do they feel secure against God's plan? Only the losers feel secure against God's plan. $^{23}$

Can you be sure that God will not have you swallowed up into the earth when you are back on land, or that He will not send a sandstorm against you? Then you will find no one to protect you. / Or can you be sure that he will not send you back out to sea, and send a violent storm against you to drown for being ungrateful?

'Think: If God were to take away your hearing and your sight and seal up your hearts, what God other than He could restore them?' Say,' Think: if the punish- 
ment of God should come to you, suddenly or foreseeably, would anyone but evil-

doers be destroyed?'

Are you sure that $\mathrm{He}$ who is in the Heaven will not make the earth swallow you

up with a violent shudder/Are you sure that He who is in the Heaven will not

send a whirlwind to pelt you with stones?/Those who went before them also disbe-

lieved - bow terrible was My condemnation!

Say, Think: if His punishment were to come to you, during the night or day, what part of it would the guilty wish to hasten? / Will you believe it when it ac-

tually bappens?

In these ayaat, the Qur'an is seeking to shake the Arab pagans out of their hubris: it forces them to engage in some soul-searching, to ask if their beliefs are founded on certainty, if they should risk their happiness upon a lie. Thus the questions: Do they feel secure...; Can you be sure...; and Are you sure... If they cannot rule out divine retribution for their unbelief, their worship of idols, their arrogance, and their violation of the rights of others, should they not guard themselves against these terrible punishments, change course, and choose belief in God and afterlife? The Arab pagans may place a wager on God or against God, but in this case, the consequences could overtake them anytime, without notice.

The Qur'an's pragmatic plea for belief was taken up by the great theologian of Islam, Al-Ghazzali of the $11^{\text {th }}-12^{\text {th }}$ centuries develops an argument similar to Pascal's wager in The Alchemy of Happiness. ${ }^{24}$ In addition, he attributes this argument to 'Ali ibn Abi Talib, cousin and son-in-law of the Prophet. However, Ghazzali does not trace his discussion of the wager back to the Qur'an. 
In a quote attributed to him - by Ghazali - 'Ali offers a very clear formulation of one version of Pascal's wager when making the case for belief with an unbeliever. "If you are right," he tells the unbeliever, "then neither of us will be any the worse, but if we are right, then we shall escape, and you will suffer." 25 It is clear from 'Ali's formulation that there are only two positions in matters of faith - you either believe or you don't. Moreover, belief and unbelief have consequences after death: for the believer, belief leads to an afterlife in heaven and unbelief is punished by an eternity in hell. 'Ali makes his case with consummate brevity, by comparing the consequences in afterlife for unbelief and belief. If the unbeliever is right, neither he nor the believer incurs any loss after death; on the other hand, if the believer is right, he goes to heaven and the unbeliever goes to hell. Alternatively, he is saying, 'If the believer is wrong he loses nothing; but if the unbeliever is wrong, he is a big loser.' The inference is clear: accept belief and avoid Hell. Nearly a thousand years later, Pascal uses similar language. Like Ali, he too weighs up "the gain and loss involved in calling heads that God exists." Pascal uses the language of the bet: Ali does not. It is appropriate that Ali should have grasped with clarity the pragmatic argument for faith, since he is reputed to have possessed the most acute and philosophical mind among the companions of the Prophet.

Al-Ghazzali elaborates upon Ali in this matter. Anticipating William James, he maintains that two conditions must be met if the wager is to have any force with an unbeliever. ${ }^{26}$ The unbeliever takes the position that "a future life is possible but that the doctrine is so involved in doubt and mystery that it is impossible to decide whether it be true or not..." In other words, the truth of 
afterlife can neither be accepted or rejected on intellectual. In the language suggested by William James, the existence of afterlife is a "live" hypothesis: that is, there exists some probability that it is true. ${ }^{27}$ Ghazzali seeks to establish the validity of the pragmatic argument - as applied to the question of afterlife - with several hypothetical examples relating to choices that have more immediate consequences. "Suppose you are about to eat food and someone tells you a serpent has spat venom on it, you would probably refrain and rather endure the pangs of hunger than eat it, though your informant may be in jest or lying." This is because he is aware that he could die from eating the food if it were truly poisoned: again, using William James' language, the consequences of choice are "momentous." Applied to the question of afterlife, Ghazzali concludes, even if one "is doubtful about a future existence, reason suggests that he should act as if there were one, considering the tremendous issues at stake." 28

Is there something in the nature of religions, especially the Abrahamic religions, that sets the stage for the Pascalian wager?

In order to gain persuasive force, Pascal's wager must satisfy four conditions articulated by William James for the wager to have some force. ${ }^{29}$ The wager gains in efficacy when a person faces an 'option' - choice between two and only two hypotheses that cannot be decided on intellectual grounds alone. In addition, the option must be 'live,' 'forced,' and produce momentous consequences. An option is 'live' when each of the hypotheses contained in it carry some chance of being true. It is 'forced' when the two choices do not overlap and there is no possibility of not making a 
choice. Finally, an option is 'momentous' when it is unique or non-repeatable, it is irreversible or cannot be undone, and the choices have important consequences. It may be noted that the live-ness of a hypothesis may depend on subjective factors - a person's emotional disposition - or it may be enhanced by reasoning and evidence, even if they are faulty in themselves. An option that satisfies all these conditions is 'genuine.'

It follows that a person facing a 'genuine option' will make a choice on pragmatic grounds, that is, by comparing the gains and losses associated with belief and unbelief. He will make the choice that yields him greater happiness. If he knows the probability that he attaches to the truth of the choices in the option, he will make the choice that yields the greatest expected happiness.

Once we grasp the elements of a 'genuine option,' it is easy to see that Christianity and Islam - implicitly if not explicitly - offer the Pascalian wager for our consideration. These religions offer an 'option' before us, a choice between accepting or rejecting its particular system of metaphysical claims whose truth, moreover, cannot be determined on the basis of reasoning and ordinary experience. The beliefs of these religions carry some degree of plausibility - they have live-ness - for some people, especially those who have been brought up in that religious tradition. The option offered by these religions - to believe or not to believe - is a 'forced' one. In these religions, the agnostic 'I don't know' is subsumed under disbelief, since the rewards only flow from belief. Moreover, since earthly life is a one-shot affair in Christianity and Islam and the verdicts passed on the Day of Judgment are irrevocable, the choice between belief and disbelief has momentous consequences.

The Pascalian wager may lose some of its force when offered 
to adherents of the Indic religions - Hinduism, Buddhism and Jainism. A belief in the transmigration of souls makes the 'option' presented by the Pascalian wager less the than momentous, since a wrong decision made in one life may be corrected in a subsequent incarnation. On the contrary, rebirth into a lower life-form - such as a slimy worm - may be sufficiently repellant to induce a choice in favor of Indic religious beliefs.

Similarly, the Pascalian wager could not have carried much traction in early Judaism which gave little importance to afterlife. ${ }^{30}$ In Judaism before the exile, afterlife consisted of a shadowy existence to which all spirits were admitted after death. Written after the exile, the Hebrew Bible was opposed to preexilic beliefs about afterlife; at the same time, it refused to imbue afterlife with ethical significance. An elaborate system of beliefs about afterlife entered into Judaism during the Hellenic period. Indeed, references to afterlife in the Hebrew Bible are rare. ${ }^{31}$ Jesus too has little to say about afterlife. Beliefs about afterlife and resurrection enter into Christianity through the writings of Paul, but following him it becomes central to the later Christian doctrine of salvation. ${ }^{32}$

Only the Qur'an makes belief in afterlife - together with the doctrines of Heaven, Hell and the Day of Judgment - an indispensable article of faith. Life on earth is a trial, a short respite between birth and death during which man is tested, and following a careful vetting of his earthly life on the Day of Judgment, he will enjoy unending felicity or suffer an eternity of Hell fire. The afterlife and themes connected to it are present in nearly every chapter of the Qur'an; and many of the early chapters contain graphic images of the conditions men and women will encounter on the Day of Judgment. The Qur'anic message of life as a test whose results 
will determine the condition of the soul in afterlife holds deep sway over the consciousness of devout Muslims. As a result, a pious Muslim spends his earthly life as a preparation for afterlife.

In view of the Qur'an's insistent preoccupation with the hereafter and individual accountability in this life and the next, it is not surprising that it - alone among the scriptures - should use this framework to propose the wager as an argument for submitting to God. On the other hand, since the Hebrew Bible does not attach any ethical significance to afterlife, it could not have proposed the wager even if it wanted to. Although Jesus had little to say about afterlife, the elaboration of a doctrine of afterlife by the early Church fathers created the preconditions for making pragmatic arguments for belief to pagan skeptics. John Ryan has documented two instances of such arguments in the writings of Christian theologians from the early centuries of the Christian era. ${ }^{33}$

It is worth pointing out that the pragmatic arguments we encounter in the Qur'an, 'Ali, Ghazzali and Pascal are implicit in the very notion of an afterlife, in which men and women face the consequences of the way they live their earthly life. In other words, although most people born into the Islamic or Christian tradition may not be able to spell out the pragmatic argument for faith in a manner that would satisfy philosophers or game theorists, this does not mean that they cannot work out - if intuitively - the gains and losses in afterlife from belief and unbelief in this life. Men and women troubled with doubts about their faith are more likely to make such comparisons the more insistently their scripture speaks of an afterlife, and the more pervasive themes about afterlife are in the sermons and discourse of the religious classes. We may expect the doctrine of divine intervention in this life to 
work in the same way, as a pragmatic argument for inducing faith in skeptics.

Pascal's wager attacks both atheism and agnosticism as irrational on pragmatic grounds. This has drawn the ire of philosophers who do not take kindly to faith. They claim to show that the different versions of the wager are logically flawed. Alternatively, even if some version of the wager is logically valid, they maintain that beliefs should not be founded on pragmatic considerations. ${ }^{34}$

These criticisms are beside the point from vantage point of God who has an overriding interest in saving souls. For Him, the question of interest is not whether the wager is logically watertight, but whether it succeeds in bringing people to belief in God. If this efficacy is the relevant criterion for judging the wager, the point is to examine the conditions that augment its efficacy.

Consider the version of the wager that hinges on a comparison of the expected values of the two choices - believing or not believing. On the one hand, these expected values will depend on the subjective probabilities that a person attaches to the truth of the theist and atheist positions. These expected values will also depend on the vividness and immediacy with which anyone views the joys of Heaven and the torments of Hell. A little reflection will suggest some strong parallels between the pragmatic arguments for belief and the arguments for not giving up (or not taking up) smoking. All this suggests that there are multiple and complex factors that will determine for any individual the expected value he places on the theist and non-theist positions.

At the same time, someone familiar with the Qur'an can see 
some of the ways in which it is likely to add to the efficacy of the pragmatic arguments. Unlike other scriptures that take belief and believers for granted - or merely denounces or threatens disbelievers with punishment - the Qur'an brings disbelievers and skeptics into its discourse, allows them to articulate their objections, and then strives mightily to overcome their objections. ${ }^{35}$ We shall show them our signs - God promises in surah Fussilat - on the far horizons and in themselves, until it become clear to them that this is the Truth. ${ }^{36}$ The Qur'an offers arguments to establish its divine origin: it challenges the Arabs to produce a sura like it, and call on anyone you can beside God if they are telling the truth; it argues them that if it had been from anyone other than God, they would have found much inconsistency in it. It argues vigorously for a single Creator-God, thus reducing the appeal of the many-gods objection to Pascal's wager. It repeatedly makes the case for afterlife: it invokes the analogy of the dead earth coming back to life; it reminds man that if God could create life in the first instance, he can also recreate it; and it appeals to the innate human thirst for a transcendent purpose to life and creation. The cumulative effect of these arguments - aimed at different levels of human understanding - is to increase the plausibility of its metaphysical claims.

In addition, the Qur'an constantly nudges man to wager on belief by a variety of means. ${ }^{37}$ It reminds him repeatedly of the torments of Hell, the self-renewing pain which its inhabitants will endure, and the endless entreaties of the inhabitants of Hell to God to give them another chance. In surah $A l$-Waqi'a, the Qur'an speaks thus of those on the Left [the inhabitants of Hell]:/ They will dwell amid scorching wind and scalding water/ in the shadow of black smoke,/ neither cool nor refreshing./ ... and you who have gone astray and denied the truth / will eat from the bitter Zaqqum, / filling your bellies with it, / 
and drink scalding water, / lapping it like thirsty camels.' Likewise, the Qur'an endlessly marshals images of felicity to give a foretaste of the joys that await the believers who will earn a place in Heaven. In the same surah, God speaks thus of the 'pleasures' that will belong to the ones brought nearest to God/in Gardens of Bliss/: On couches of well-woven cloth/ they will sit facing each other; / everlasting youths will go round among them/with glasses, flagons, and a pure liquid/ that causes no beadache or intoxication;/ [there will be] any fruit they want;/ the meat of any bird they like;/ and beautiful companions/ like bidden pearls; / a reward for what used to do./ They will hear no idle or sinful talk there/ only clean and wholesome speech. These are but samples of the diverse images that the Qur'an uses to illustrate (in terms of sensory experience) the nature of the pain and pleasures of afterlife.

In addition, the Qur'an makes a strong linkage between our beliefs, choices and actions in this life and the chances of going to Hell or Heaven. God keeps a meticulous account of what we do in this life, and on the Day of Judgment He will decide on our fate in afterlife based on a weighing of these accounts. So that men and women will not pin their hopes on being forgiven in afterlife, the Qur'an emphasizes that death is final, that we are given only one life on earth, and the time for seeking forgiveness is before death. There is no escape from Hell and no expulsion from Heaven: both are eternal. Acting against the human propensity to put off difficult decisions to a later date, the Qur'an reminds man that the time and place of his death have been fixed but unknown to him; death may overtake him at any instant leaving him no time to repent. The Qur'an repeatedly compares the brevity of earthly life to a hereafter that is everlasting. In short, by speaking repeatedly of human mortality, afterlife, Day of Judgment, Hell and Heaven, 
the Qur'an is likely to nudge its readers to place their bets on belief.

Unusually for a scripture, the Qur'an does not take the man of faith for granted, nor does it speak exclusively to him. On the contrary, it speaks to man as he is: God created man in the finest state but brought bim down to the lowest of the low. Man is rub (spirit) coupled to a nafs (ego), dominated by appetites, passions, and ambitions that act to anchor him to this world, obscuring the urge to return to his spiritual home. In addition, man is endowed with reasoning, a mode of knowing that allows him to navigate the world of sensory experiences. When man becomes deeply attached to the life of the nafs, his sensory experiences atrophy, they become selfcontained instead of serving as pointers to a higher reality. At the same time, his rational faculty becomes hegemonic: it rejects all other forms of knowing. In other words, it is content to work only with the data of his atrophied sensory experience and, therefore, becomes skeptical of the knowledge gained through other modes of knowing. Unremittingly, the Qur'an seeks to draw this skeptical man back towards God by facilitating his return to higher modes of knowing. In seeking to save man, the Qur'an employs all the rhetorical arts of persuasion, even using reason to establish its limits, and, hence, opening him to higher modes of knowing. Given the Qur'an's comprehensive program of salvation, it would be surprising if it did not employ pragmatic arguments to make the case for faith on rational and utilitarian grounds.

Those who wish to take a sociological approach to the Qur'an's use of pragmatic arguments may choose to explain the pragmatic 
arguments as a response to the intellectual character of Mecca where the Qur'an was first revealed and where Prophet Muham$\operatorname{mad}(s)$ spent the first thirteen years of his career as a prophet. ${ }^{38}$ Contrary to the prejudices of many Western writers, the Prophet was not born among 'savage' Bedouins who lived off their camels and engaged endlessly in skirmishing with each other. On the contrary, he was born to the ancient and noble clan of Quraish, who were ancient guardians of the Kaaba - the central shrine of Arabia - as well as its leading traders. Nevertheless, it is true that the citydwelling traders of Makka as well as the Bedouins living in much of the Arabia peninsula were pagans - almost the only people in the ancient Near East who had not entered into the rites of a revealed religion - who worshipped a multiplicity of gods and did not believe in an afterlife. As the livelihood of most Meccans depended on trading that took them on journeys south to Yemen and Ethiopia and North and West to Syria and Iraq, their extensive travels, their familiarity with diverse cultures, and their experience with trade in different commodities, business partnerships, lending and borrowing, and currency exchanges must have given a strongly rationalist character to their thinking. As Prophet Muhammad $(s)$ spoke to this sophisticated audience, rationalist, empirical, disbelieving of revelations, miracles and afterlife, he had to address their skepticism and earth-rooted vision of life with every rhetorical and rational means that had a chance of denting their skepticism. In support of this interpretation, the sociologist may draw attention to the fact that in all but one instance, the pragmatic case for belief is made in the Meccan chapters. ${ }^{39}$ 


\section{Endnotes}

1 Unless otherwise indicated, the translations in this paper are from Abdul Haleem, The Qur'an: English translation (Oxford: Oxford University Press, 2010).

2 Qur'anic references in this paragraph: the straight path...(1, 6); created man in the finest state...(95, 4-5); something as small as a gnat (2, 26); without any visible support $(31,10)$; look around... see any flaw $(67,3)$; spreading and closing their wings $(67,19)$; ships, sailing like floating mountains 42, 32); pure milk, sweet to the drinker $(16,66)$; etc.

3 Qur'anic references: most people will not believe...(12,103).

4 Blaise Pascal, Pensées, translated with an introduction by A. J. Krailsheimer (London: Penguin Books, 1995):122-23.

5 Do not hesitate then: but why? In wagering for God there is eternal happiness to be gained if He exists, and no loss if He does not exist. In wagering against God there is eternal damnation if He exists, and nothing is lost if He does not exist. In such a calculation, the wager for God is to be preferred since the outcomes of this choice are superior or no worse than the outcomes of wagering against God. Is Pascal's assumption of losing nothing (if God exists) a bit simplistic? This assumption holds if the believer and disbeliever live the same life and their disposition in afterlife depends only on their belief, not on how they live their lives. If the believer submits to the religious life, is that a pain endured? Only perhaps, at the point that he gives up some of his earthly pleasures to enter into the religious life: for once he has accepted the religious life its joys may compensate - or more than compensate - for the more earthy pleasures sacrificed.

6 Qur'anic references in this paragraph: those who doubt that they will meet their lord $(41,54)$; They say, 'Our hearts are encased...' $(41,5)$; smoke $(41,11)$; the Day, when God's enemies ... $(41,19)$; be allowed to make amends $(41,24)$; His signs $(41,37)$; certainly give life to the dead $(41,39)$. 
7 There is only the life of this world: we die, we live, but we will never be resurrected: 23,37 .

8 In Surah Al-An'aam (6, 29), God says about the pagans, They say, There is nothing beyond our life in this world: we shall not be raised from the dead.'

9 New Qur'anic references in this paragraph: those who have rejected the revelations of God will be the losers $(39,63)$.'

10 In numerous ayaat, the pagans justify their rejection of the Qur'an because - they say - it goes agains the teachings of their ancestors. See 7, 28; 14, 9-12; 23, 26; 26, 137.

11 Qur'anic reasoning here comes closest to the maximin version of Pascal's wager, on the assumption of decision-making under uncertainty, that is, where the person cannot attach any probability to the options he faces: (a) the Qur'an is true, and (b) the Qur'an is not true. In the maximin version, the individual will "choose that action the worse outcome of which is superior to the worst outcomes of the other alternative actions." See Jeff Jordan, Pascal's wager: Pragmatic arguments and belief in God (Oxford: Clarendon Press, 2006): 14.

12 Sayyid Abul A'ala Maududi, Tafheem-ul-Qur'an, volume 4 (Lahore: Idara Tarjuman ul Qur'an, 1984): 468-69.

13 Qur'anic reference in this paragraph: Whenever We let him taste some of Our mercy...(41, 50); We do not believe the message...(14, 9).

14 In surah Al-Kabf, the arrogant disbeliever in the parable about two men walks into his garden and boasts, I do not think this will ever perish,/ or that the Last Hour will every come - even if I were to be taken back to my Lord, I would certainly find something even better there. (18, 35-6).

15 Implicitly, the Qur'an makes a third pragmatic argument: it concerns the practical benefits that individuals and society in this life from living according to Islamic precepts. Since sincere belief in Islam will keep men and women away from forbidden activities - lying, mur- 
der, stealing, fornication, drinking, gambling, usury, freeing slaves, etc - and induce them to good actions - speaking the truth, forbidding evil and enjoining good, perform the salat, engage in obligatory and voluntary charity, show respect to parents, etc - it follows that Islam produces, to the extent that is practiced sincerely, a moral and humane society. In Surah Ankabut (45), this is stated explicitly with respect to the obligatory prayers: prayer restrains outrageous and unacceptable behavior. In this verse, the Qur'an makes a positive, verifiable claim about the impact of salaat on the behavior of the worshiper.

16 Here is a list of the pragmatic arguments I have identified in the Qur'an: 4, 39; 6, 46-47; 6: 81-83; 7, 97-99; 10, 50-51; 11:28; 11, 63; 11:87-88; 17: 68-69; 28,71; 31, 21; 46,10; 40, 28-29; 41, 52; 67, 16.

17 Bahauddin, The drowned book: Ecstatic and earthy reflections, translated by Coleman Barks and John Moyne (San Franciso: HarperSanFranciso, 2005): 77.

18 Qur'anic references in this paragraph: Say, 'Have you thought, what if this revelation really is from God and you will reject it?: 41, 52; I do not think the Hour will ever come: 41, 50; When they are told, 'Follow what God has sent down,' they say: 'We shall follow what we saw our forefathers following. What! Even if Satan is calling them to the suffering of the Blazing Flame? : 31, 21.

19 Qur'anic references: Have you thought $(46,10)$; When they are told $(31,21)$.

20 Qur'anic references in this paragraph: 'My people, can you not see? What if I am acting on clear evidence from my Lord? (11, 87-88: 'My people, think... $(11,28)$.

21 Qur'anic references: humiliating punishment: 4, 37; arrogant, boastful ...miserly, and do not believe in Him and the Last Day: 4, 36-38; What harm would it do them to believe in God and the Last Day, and give charitably from the sustenance God has given them?: 4, 39 . 
22 Qur'anic reference: fate of the people of Noah, 'Ad, Thamud, and those who came after them: 50, 12-14.

23 This and the next four quotations are from: 7, 97-99; 17, 68, 69; 6, 46, 47; 67, 16-18; 10, 50, 51.

24 We do not know if the Qur'an's pragmatic arguments for belief were taken up by other Islamic writers before the modern period; this subject has yet to receive any scholarly attention from modern scholars. Ibn Kathir (1301-1373), the great classical exegete on the Qur'an had very little to say on surah Fussilat, ayat 52. Isma'il Ibn Kathir, Tafseer Ibn Kathir, Juzz' 25, tr. Muhammad Saed Abdul-Rahman (London: MSA Publication, 2009): 38-39.

25 Al-Ghazzali, Abu Hamid Muhammad, The alchemy of happiness, translated by Claud Field, (NY: M. E. Sharpe, 1991): 42-43.

26 In order to gain persuasive force, the pragmatic arguments must satisfy three conditions first articulated by William James, although - as we have seen - two of these conditions were anticipated by AlGhazzali. These arguments apply when a person faces an 'option' where an option is defined as a choice between two hypotheses that is 'live,' 'forced,' and has momentous consequences. An option is live when both propositions are probable truths, that is, the truth of neither proposition can be established with certainty on intellectual grounds. It is forced when the two choices it offers are disjoint and there is no possibility of not making a choice. Finally, the option has momentous consequences. It may be noted that whether a proposition is live may depend on entirely on subjective factors - a person's emotional disposition - or the probability of its being true may be supported by reasoning and evidence. An option is momentous when it is unique or non-repeatable, it is irreversible or it cannot be undone, and the choices have important consequences or they cannot be ignored. An option that satisfies all three conditions is 'genuine.' 
27 William James, "The will to believe," in Essays in pragmatism (New York: Hafner Publishing Company, 1948): 88-90.

28 Al-Ghazzali, The alchemy: 41-43. Asin Palacios has shown that Pascal was familiar with the writings of Ghazzali, and it is likely that he derived the argument in his wager from the latter. See Asín Palacios, Los precedents musulmanes del Pari' de Pascal (Santander, 1920).

29 James, "The will to believe:" 88-90.

30 In the Jewish scripture, God takes a lively interest in the collective life of the Jews; He promises earthly rewards for obeying His commands, and warns of punishments for deviation from the same. To the extent that these rewards and punishments are collective, they are likely to lose much of their force in the choices individuals make about faith and unbelief.

31 The Israelites before the exile did believe in an afterlife but it was unremarkable. After their death, the spirits of all humans went to a land below the earth, variously called Sheol, Earth, or the Pit. There was no accounting - Judgment - that preceded passage to afterlife; that is, there is no differentiation in afterlife between the wicked and the righteous. The Hebrew Bible - written in the post-exilic period - was opposed to many of the preexilic beliefs about afterlife and practices connected with these beliefs, such as necromancy. As a result, references to afterlife in the Hebrew Bible are rare, and, in some texts, such a belief is negated, as in Ecclesiastes: 9.4-5 and 10. Elaborate beliefs about afterlife, with accounting of deeds and bodily resurrection, entered into Judaism during the Hellenistic period. See Bruce M. Metzger and Michael D. Coogan, eds., The Oxford companion to the Bible (New York and Oxford: Oxford University Press, 1993): 15-16; Daniel Cohn-Sherbok, "Death and immortality in the Jewish tradition," in: Paul and Linda Badham, Death and immortality in the religions of the world (New York: Paragon House, 1987): 24-36. 
32 Paul Badham, "The Christian hope today," in: Paul and Linda Badham, Death and immortality in the religions of the world (New York: Paragon House, 1987): 37-38.

33 John Ryan, "The argument of the wager in Pascal and others," New Scholasticism 19, 3(1945): 235-38.

34 See Jeff Jordan, Pascal's wager, Simon Blackburn, Truth: A guide (Oxford and New York: Oxford University Press, 2005): 3-13; Alan Hájek., "Waging war on Pascal's wager," The Philosophical Review 112, 1 (January 2003): 27-56; Alan Hájek, "Pascal's Wager", The Stanford Encyclopedia of Philosophy (Summer 2011 Edition), Edward N. Zalta (ed.), forthcoming URL = $<$ http://plato.stanford.edu/archives/sum2011/entries/pascalwager $/>$.

35 For the Qu'ran's dialectical approach see, M. Shahid Alam, Alam, The Quranic Paradigm: A Contest Over Man (November 9, 2010). Available at SSRN: http://ssrn.com/abstract=1706449. For the most part, the Hebrew Bible deals with sinners not disbelievers. When it encounters disblievers, that is, people who have taken to idol worship or the worship of gods other than Yehweh, the Jewish prophets do not reason with them to bring them back to the worship of one God. Thus, when God informs Moses during his retreat to Mount Sinai that the Israelites have taken to worshipping a golden calf, he orders the Levites to "go back and forth from gate to gate throughout the camp, and slay brother, neighbor, and kin (Exodus: 32, 27)." The translation is from Adele Berlin and Marc Zvi Brettler, eds., The Jewish Study Bible (Oxford and New York: Oxford University Press, 2004).

36 Qur'anic reference: We shall show them... $(41,53)$; produce a sura like it... (10, 38); it had been from anyone other than God...(4:82)..

37 ...those on the Left ...the ones brought nearest to God...(56, 41-55, 11-26). 
38 Parenthitically, it is important to add here that the sociological need not necessarily contradict the metaphysical; after all, God works through history.

39 The exception is 4,39 . 